
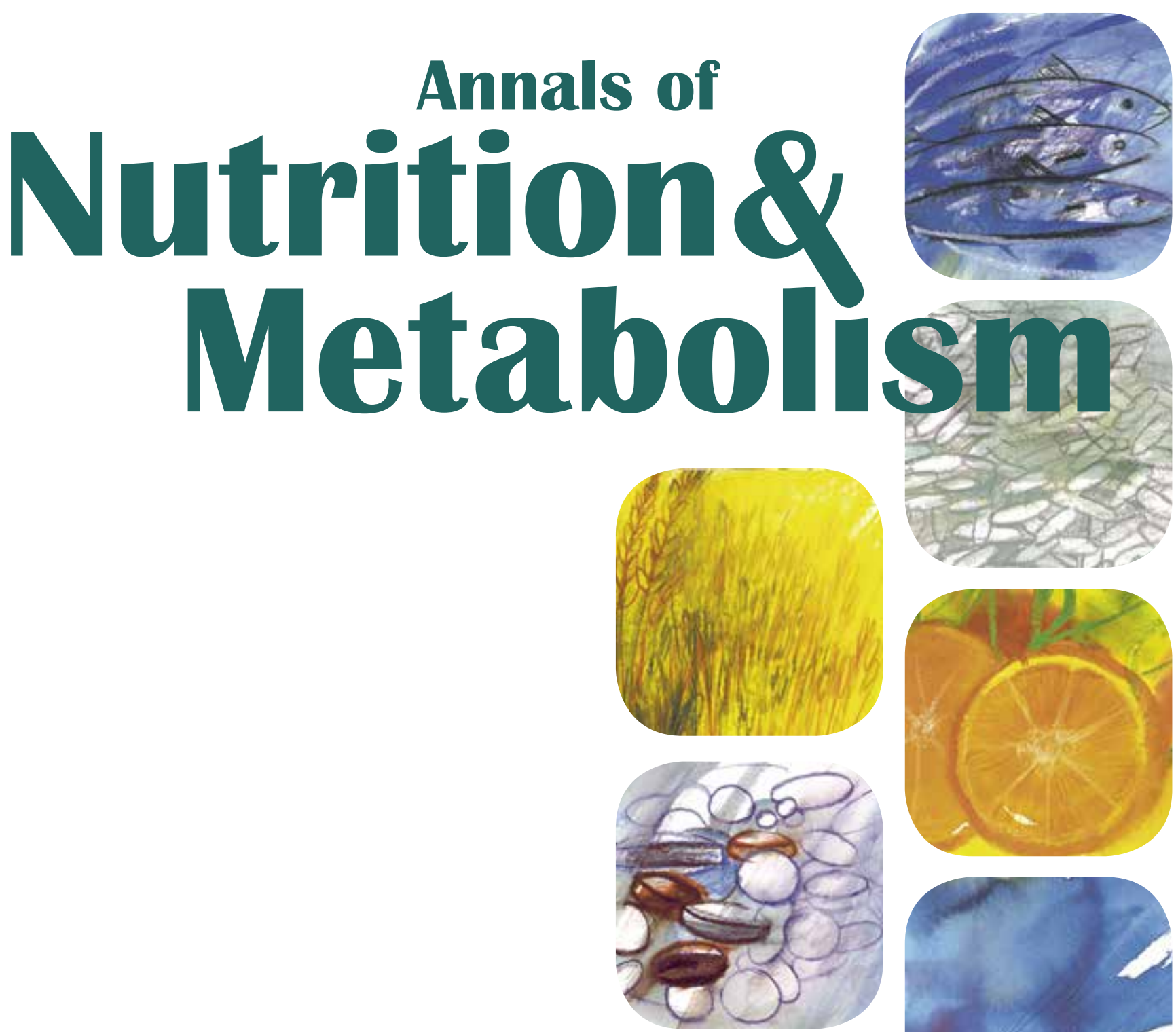

Medical and Scientific Publishers Basel · Freiburg · Paris .

London - New York .

New Delhi · Bangkok · Beijing ·

Tokyo · Kuala Lumpur ·

Singapore $\cdot$ Sydney 


\section{Evidence-Based Research in Pediatric Nutrition}

\author{
Editors \\ H. Szajewska \\ R. Shamir
}

Evidence-Based Research in Pediatric Nutrition

Editors: H. Szajewska (Warsaw):

R. Shamir (Petach-Tikva)

X +112 p., 4 fig., 8 tab., 2013

CHF 148.- / EUR 123.- / USD 174.00 (hard cover) CHF 178.- / EUR 148.- / USD 209.00 (online) Online version for institutional purchase Prices subject to change

EUR price for Germany, USD price for USA only ISBN 978-3-318-02456-2 (hard cover) e-ISBN 978-3-318-02457-9

World Review of Nutrition and Dietetics, Vol. 108

Series Editor: Koletzko, B. (Munich)

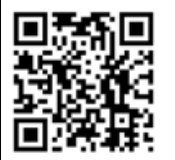

Dear Librarian

I have reviewed this publication and would like to recommend it for our library. Recommended by:

Department:

Date:

\section{Signature:}

Orders may be placed with any bookshop, subscription agency, directly with the publisher or through a Karger distributor.
Recognition of evidence-based medicine is not only increasing rapidly, but it has become essential to pediatric nutrition. Starting with some methodological issues - discussing systemic reviews, meta-analyses and clinical trials - this publication then concisely summarizes current knowledge as well as ignorance and uncertainty regarding selected aspects of childhood nutrition. These aspects include functional gastrointestinal disorders, issues concerning various kinds of milk, complementary foods, enteral nutrition, celiac disease or obesity. Contents are based on evidence and summarize current guidelines; moreover, when there is no clear evidence, they provide some food for thought.

Overall, this publication has been written to enable the clinician to make informed decisions regarding pediatric nutrition.

\section{Contents}

- Preface: Szajewska, H.; Shamir, R.

\section{Methodological Considerations}

- Importance of Systematic Reviews and

Meta-Analyses in Pediatric Nutrition: Szajewska, H.

- Strengths and Weaknesses of Observational

Nutritional Studies: Patro-Gołąb, B.; Szajewska, H.

- Scientific Standards for Human Intervention Trials Evaluating Health Benefits of Foods, and Their Application to Infants, Children and Adolescents: Woodside, J.V.; Koletzko, B.V.; Patterson, C.C.; Welch, R.W.

\section{Impact of Early Nutrition on Later Outcomes}

-Early Nutrition and Health: Short- and Long-Term

Outcomes: Gruszfeld, D.; Socha, P.

\section{Issues in Infant Feeding}

- Probiotics, Prebiotics, and Dietary Fiber in the Management of Functional Gastrointestinal

Disorders: Horvath, A.; Szajewska, H.

- Growing-Up Milk: A Necessity or Marketing?

Przyrembel, H.; Agostoni, C.

- Cow's Milk and Goat's Milk: Turck, T.

- The Timing of Introduction of Complementary Foods and Later Health: Agostoni, C.; Przyrembel, H.

- Dietary Interventions for Primary Allergy

Prevention - What Is the Evidence? von Berg, A.

- Vitamin and Mineral Supplementation of Term Infants: Are They Necessary? Lubetzky, R.; Mandel, D.; Mimouni, F.B.

\section{Issues in Nutrition of Children}

- Enteral Nutrition: Kolaček, S.

- Celiac Disease - Prevention Strategies through Early Infant Nutrition: Chmielewska, A.; Szajewska, H.; Shamir, R.

- Interventions for Treating Obesity in Children: De Miguel-Etayo, P.; Bueno, G.; Garagorri, J.M.; Moreno, L.A. 
An Official Journal of

International Union of Nutritional Sciences (IUNS)

\section{IUNS Editorial Representative}

I. Elmadfa, Vienna

\footnotetext{
Federation of European Nutrition Societies (FENS)

fens
}

FENS Editorial Representative

D. Lairon, Marseilles

European Neutraceutical

Association (ENA)

ENA Editorial Representative

M. Lamprecht, Graz

Ernährung (DGE)

\section{DGE Editorial Reresentative}

H. Oberritter, Bonn

An Official Journal of

International Union of Nutritional Sciences (IUNS)

Federation of European Nutrition Societies (FENS)

European Neutraceutical Association (ENA)

Deutsche Gesellschaft für Ernährung (DGE)

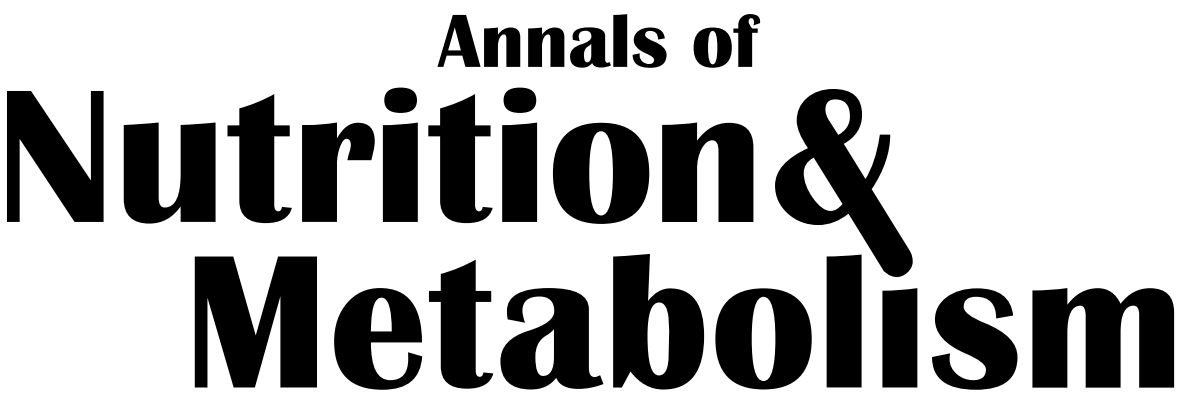

Founded 1959 as 'Nutritio et Dieta' by E. Azerad, H. Kapp and J. Trémolières. Continued by A. Wretlind (1961-1969). Continued by N. Zöllner (1970-1990) as 'Nutrition and Metabolism' (1970-1980), since 1980 integrating 'Annales de la Nutrition et de l'Alimentation', continued as 'Annals of Nutrition and Metabolism. Continued by G. Wolfram (1991-1999), Continued by I. Elmadfa (2000-2010)

\section{Editor}

B. Koletzko, Munich

\section{Assistant Editor}

B. Kessler, Munich

\section{Associate Editors}

P.S.W. Davies, Brisbane, Qld.

L. de Groot, Wageningen

G. Desoye, Graz

A. Gil, Granada

J. Heinrich, Neuherberg

R. Meier, Liestal

S. Nagata, Tokyo

U. Nöthlings, Bonn

L. Poston, London

M.B. Zimmermann, Zurich

\section{Editorial Board}

A. Astrup, Copenhagen

A. Berg, Freiburg

Z.A. Bhutta, Karachi

S.C. Bischoff, Stuttgart

F. Branca, Rome

R. Brigelius-Flohé, Nuthetal

P.C. Calder, Southampton

S. Carlson, Kansas City, Kan.

I. Cetin, Milan

R.J. Deckelbaum, New York, N.Y.

T. Decsi, Pécs
C.J. Field, Edmonton

K. Godfrey, Southampton

R. Hakkak, Little Rock, Ark.

W.S. Harris, Sioux Falls, S. Dak.

H. Hauner, Munich

M. Hernández-Triana, Havana

H. Heseker, Paderborn

E. Hypponen, London

J. Kopecky, Prague

M. Krawinkel, Giessen

M. Lamprecht, Graz

W. Langhans, Zurich

J. Linseisen, Neuherberg

O. Ljungqvist, Örebro

J.A. Martinez, Pamplona

H.J. McArdle, Aberdeen

Y. Naito, Kyoto

P.W. Nathanielsz, San Antonio, Tex.

H. Oberritter, Bonn

R. Saffery, Parkville, Vic.

W.H.M. Saris, Maastricht

L. Serra-Majem,

Las Palmas de Gran Canaria

C. Sieber, Nürnberg

A.P. Simopoulos, Washington, D.C.

P. Singer, Petah Tikva

N.W. Solomons, Guatemala City

P. Stehle, Bonn

I. Thorsdottir, Reykjavik

K. Tontisirin, Nakhon Pathom

R. Uauy, Santiago

S. Villalpando, Cuernavaca Morelos

T. Yoshikawa, Kyoto

A. Zittermann, Bad Oeynhausen
Printed in Switzerland on acid-free and non-aging paper (ISO 9706) by Reinhardt Druck, Base
Appears every 6 week: 2 volumes per year (8 issues) 


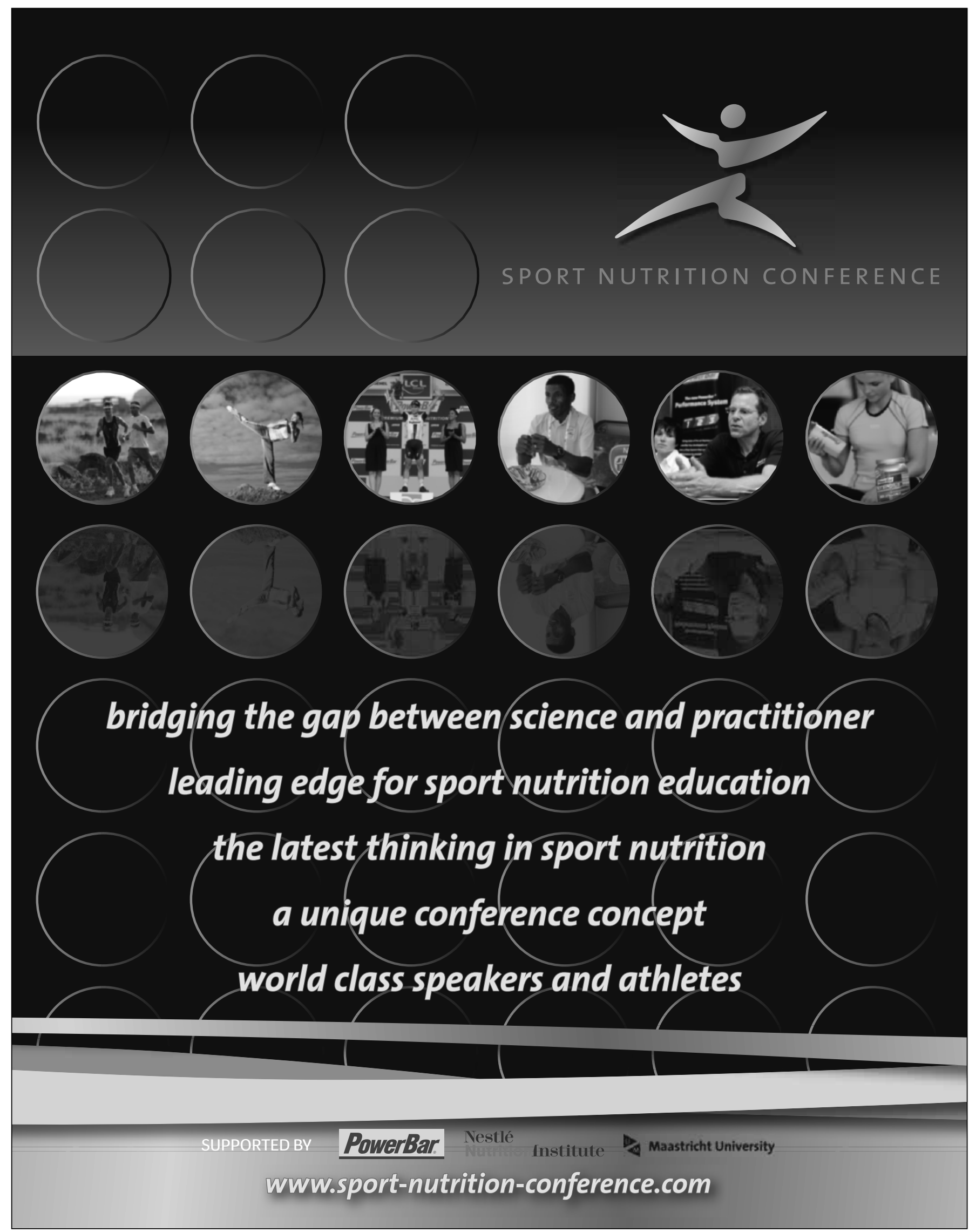




\section{Nutrition \& Metabolism}

\section{Contents}

Systematic Reviews

32 Maternal and Paternal Body Mass Index and Offspring Obesity: A Systematic Review

Patro, B.; Liber, A.; Zalewski, B. (Warsaw); Poston, L. (London); Szajewska, H. (Warsaw); Koletzko, B. (Munich)

42 Effects of Inulin-Type Fructans on Appetite, Energy Intake, and Body Weight in Children and Adults: Systematic Review of Randomized Controlled Trials Liber, A.; Szajewska, H. (Warsaw)

Original Papers

1 Effect of Multispecies Probiotic Supplements on Metabolic Profiles, hs-CRP, and Oxidative Stress in Patients with Type 2 Diabetes

Asemi, Z. (Kashan); Zare, Z. (Tehran); Shakeri, H.; Sabihi, S. (Kashan); Esmaillzadeh, A. (Isfahan)

10 Influence of Exclusive Enteral Nutrition Therapy on Bone Density and Geometry in Newly Diagnosed Pediatric Crohn's Disease Patients

Werkstetter, K.J.; Schatz, S.B.; Alberer, M.; Filipiak-Pittroff, B.; Koletzko, S. (Munich)

17 Heart Surgery Stems Increased Nutritional Risk, Expressed during the Course of Stationary Rehabilitation

Boban, M.; Persic, V. (Opatija/Rijeka/Osijek); Miletic, B. (Opatija); Kovacicek, K. (Zagreb); Madzar, Z. (Opatija/Rijeka)

25 Lack of Association of Homocysteine Concentrations with Oxidative Stress, Alterations in Carotid Intima Media Thickness and Endothelial Reactivity in Prepubertal Children

Suano de Souza, F.I.; D’Almeida, V.; Fonseca, F.L.A.; Hix, S.; Miranda, R.; Gomes de Torres Rossi, R.; Ribeiro, R.; Saccardo Sarni, R.O. (São Paulo)

55 Iron Absorption following a Single Oral Dose of Ferrous Sulfate or Ferric Gluconate in Patients with Gastrectomy

Santarpia, L.; Pagano, M.C.; Cuomo, R.; Alfonsi, L.; Contaldo, F.; Pasanisi, F. (Naples)
62 Screening for Cronobacter Species in Powdered and Reconstituted Infant Formulas and from Equipment Used in Formula Preparation in Maternity Hospitals Siqueira Santos, R.F.; da Silva, N.; Amstalden Junqueira, V.C. (Campinas); Kajsik, M. (Nottingham/Bratislava); Forsythe, S. (Nottingham); Pereira, J.L. (Campinas)

69 Does Low Birth Weight Predict Hypertension and Obesity in Schoolchildren?

Zarrati, M.; Shidfar, F. (Tehran); Razmpoosh, E. (Qazvin); Nezhad, F.N.; Keivani, H.; Hemami, M.R. (Tehran); Asemi, Z. (Kashan)

77 Dyslipidemia in Pediatric Systemic Lupus Erythematosus: The Relationship with Disease Activity and Plasma Homocysteine and Cysteine Concentrations

Ortiz, T.T.; Terreri, M.T.; Caetano, M.; Souza, F.S.; D’Almeida, V.; Sarni, R.O.S.; Hilário, M.O.E. (São Paulo)

83 Adding Pineapple Juice to a Polyethylene GlycolBased Bowel Cleansing Regime Improved the Quality of Colon Cleaning

Altınbas, A.; Aktas, B.; Yılmaz, B.; Ekiz, F.; Deveci, M. (Ankara); Basar, O. (Antalya); Simsek, Z.; Coban, S. (Ankara); Tuna, Y. (Antalya); Uyar, M.F.; Yuksel, O. (Ankara)

88 The Association between n-3 Polyunsaturated Fatty Acid Levels in Erythrocytes and the Risk of Rheumatoid Arthritis in Korean Women Lee, A.L.; Park, Y. (Seoul)

103 Effects of Parenteral Nutrition Formulas on Plasma Lipid Profile in Children with Bone Marrow Transplantation

Baena-Gómez, M.A.; de la Torre Aguilar, M.J. (Cordoba); Mesa, M.D. (Granada); Llorente-Cantarero, F.J.;

Pérez Navero, J.L.; Gil-Campos, M. (Cordoba)

111 Beneficial Effects of Fresh and Fermented Kimchi in Prediabetic Individuals

An, S.-Y.; Lee, M.S.; Jeon, J.Y.; Ha, E.S. (Suwon); Kim, T.H. (Goyang); Yoon, J.Y.; Ok, C.-O.; Lee, H.-K.; Hwang, W.-S.; Choe, S.J.; Han, S.J.; Kim, H.J.; Kim, D.J.; Lee, K.-W. (Suwon)

\section{KARGER}

E-Mail karger@karger.com www.karger.com
(C) 2013 S. Karger AG, Basel

Access to full text and tables of contents, including tentative ones for forthcoming issues: www.karger.com/anm_issues 
120 Assessing Early Growth and Adiposity: Report from an EarlyNutrition Academy Workshop

Ward, L.C. (Brisbane, Qld.); Poston, L. (London); Godfrey, K.M. (Southampton); Koletzko, B. (Munich) on behalf of the Early Nutrition Academy

131 Fruit and Vegetables: Intake and Sociodemographic Determinants among Portuguese Mothers

Franchini, B.; Poínhos, R. (Porto); Klepp, K.-I. (Oslo);

Vaz de Almeida, M.D. (Porto)

139 Nutrient Composition of Cirina forda (Westwood)Enriched Complementary Foods

Adepoju, O.T.; Daboh, O.O. (Ibadan)

145 Nutrient Intake in Infancy and Body Mass Index at Six Years in Two Population-Based Cohorts Recruited before and after Revision of Infant Dietary Recommendations

Thorisdottir, B.; Gunnarsdottir, I.; Thorisdottir, A.V.; Palsson, G.I.; Halldorsson, T.I.; Thorsdottir, I. (Reykjavik)

152 Micronutrient Status of Children Receiving Prolonged Enteral Nutrition

Gottrand, M.; Muyshont, L.; Couttenier, F.; Beghin, L.;

Martigne, L.; Coopman, S.; Turck, D.; Michaud, L.; Guimber, D.; Gottrand, F. (Lille)
159 Comparative Effects of Carbohydrate versus Fat Restriction on Serum Levels of Adipocytokines, Markers of Inflammation, and Endothelial Function among Women with the Metabolic Syndrome: A Randomized Cross-Over Clinical Trial

Rajaie, S.; Azadbakht, L.; Saneei, P.; Khazaei, M.; Esmaillzadeh, A. (Isfahan)

168 Evaluation of Plasma Trace Element and Mineral Status in Children and Adolescents with Phenylketonuria Using Data from InductivelyCoupled-Plasma Atomic Emission and Mass Spectrometric Analysis

Knerr, I. (Dublin); Blessing, H.; Seyferth, S. (Erlangen); Watling, R.J. (Crawley, W.A.); Chaudhri, M.A. (Erlangen)

Meeting Report

96 Health Significance of Fat Quality in the Diet

Nettleton, J.A. (Denver, Colo.); Villalpando, S. (Cuernavaca); Cassani, R.S.L. (Ribeirão Preto); Elmadfa, I. (Vienna)

Commentary

60 Irisinemia: A Novel Concept to Coin in Clinical Medicine?

Sanchis-Gomar, F.; Perez-Quilis, C. (Valencia)

\section{New!}
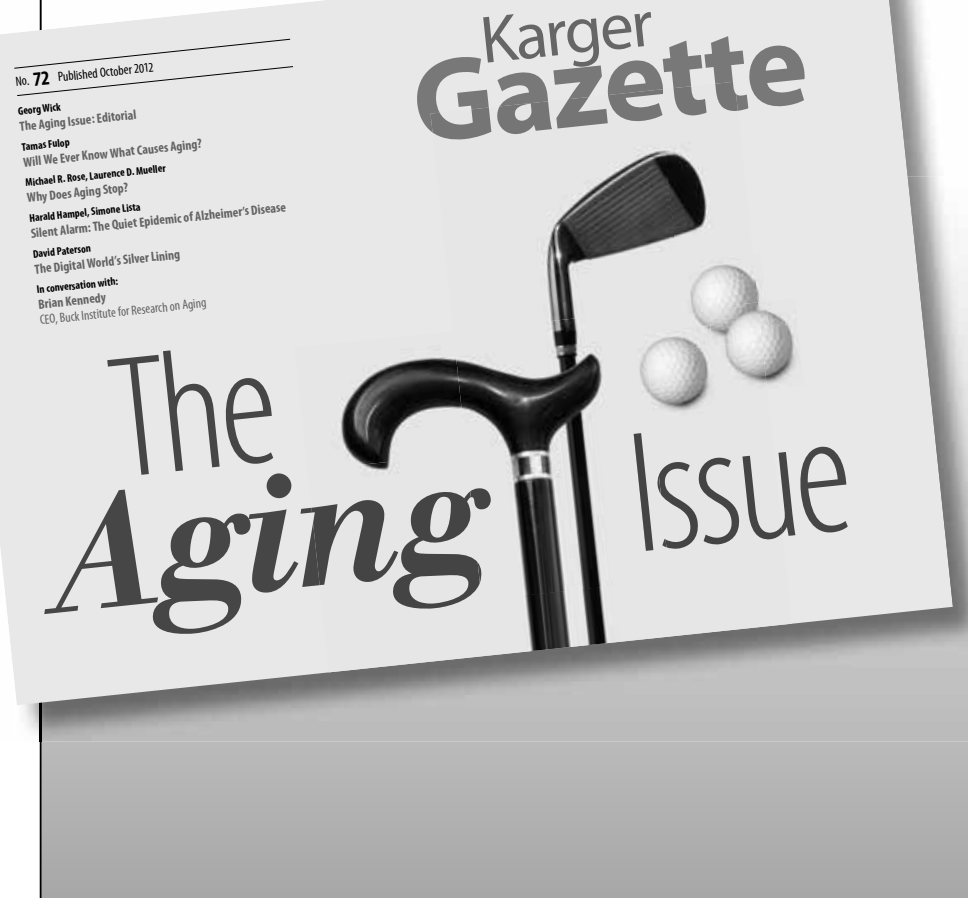

KI12305
For over 40 years the Karger Gazette has been distributed to a growing audience worldwide. Published once a year in newspaper format, it highlights advances in biomedicine and clinical practice, introduces personalities, portrays research institutes and chronicles milestones in the history of Karger Publishers in a lively and readable style. With invited contributions by experts from all over the world, each issue is devoted to a special topic of current interest.

In the latest issue, read free articles on the causes of the aging process, why aging stops in later adult life, the quiet epidemic of Alzheimer's Disease, internet use by seniors, and more.

For your free print subscription $\rightarrow$ gazette@karger.com

Read it online $\rightarrow$ www.karger.com/gazette

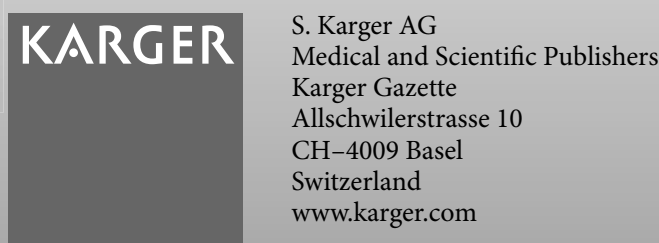

\section{KARGER}

E-Mail karger@karger.com www.karger.com
(C) 2013 S. Karger AG, Basel 


\section{Nutrition\& Metabolism}

ISSN Print Edition: 0250-6807

ISSN Online Edition: 1421-9697

Journal Homepage: www.karger.com/anm

Publication Data: 'Annals of Nutrition and Metabolism' is published 8 times a year. Volumes 62 and 63 , each with 4 issues, appear in 2013 .

Copyright: (c) 2013 S. Karger AG, Basel (Switzerland). All rights reserved. No part of this publication may be translated into other languages, reproduced or utilized in any form or by any means, electronic or mechanical including photocopying, recording, microcopying, or by any information storage and retrieval system, without permission in writing from the publisher or, in the case of photocopying, direct payment of a specified fee to the Copyright Clearance Center.

Disclaimer: The statements, opinions and data contained in this publication are solely those of the individual authors and contributors and not of the publisher and the editor(s). The appearance of advertisements in the journal is not a warranty, endorsement, or approval of the products or services advertised or of their effectiveness, quality or safety. The publisher and the editor(s) disclaim responsibility for any injury to persons or property resulting from any ideas, methods, instructions or products referred to in the content or advertisements.
Subscription Rates: Subscriptions run for a full calendar year. Prices are given per year. Personal subscription:

Print or Online

CHF 1019.-

EUR 822.-

USD 1009.00

Print+Online combined CHF 1115.-

EUR 900.-

postage and handling (added to print and print+online)

CHF 83.20 Overseas

EUR 44.80

USD 76.80

Institutional subscription:

Print or Online

Print+Online combined

CHF 3398.-

CHF 3738.-

EUR 2740.-

EUR 3014.-

USD 3700.00

postage and handling (added to print and print+online)

CHF 72.- Europe, CHF 104.- Overseas

EUR 56.-

USD 96.00

Airmail surcharge: CHF 70.- / USD 66.00

Discount subscription prices:

Please enquire about reduced rates for members of affiliated societies.
Back Volumes and Single Issues: Information on availability and prices of single print issues and print or electronic back volumes can be obtained from Customer Service atservice@karger.com.

Bibliographic Indices: This journal is regularly listed in bibliographic services, including Current Contents ${ }^{\circledR}$ and PubMed/MEDLINE.

Photocopying: This journal has been registered with the Copyright Clearance Center (CCC), as indicated by the code appearing on the first page of each article. For readers in the US, this code signals consent for copying of articles for personal or internal use, or for the personal or internal use of specific clients, provided that the stated fee is paid per copy directly to

Copyright Clearance Center Inc.

222 Rosewood Drive

Danvers, MA 01923 (USA)

A copy of the first page of the article must accompany payment. Consent does not extend to copying for general distribution, for promotion, for creating new works, or for resale. In these cases, specific written permission must be obtained from the copyright owner,

S. Karger AG, P.O. Box

CH-4009 Basel (Switzerland).

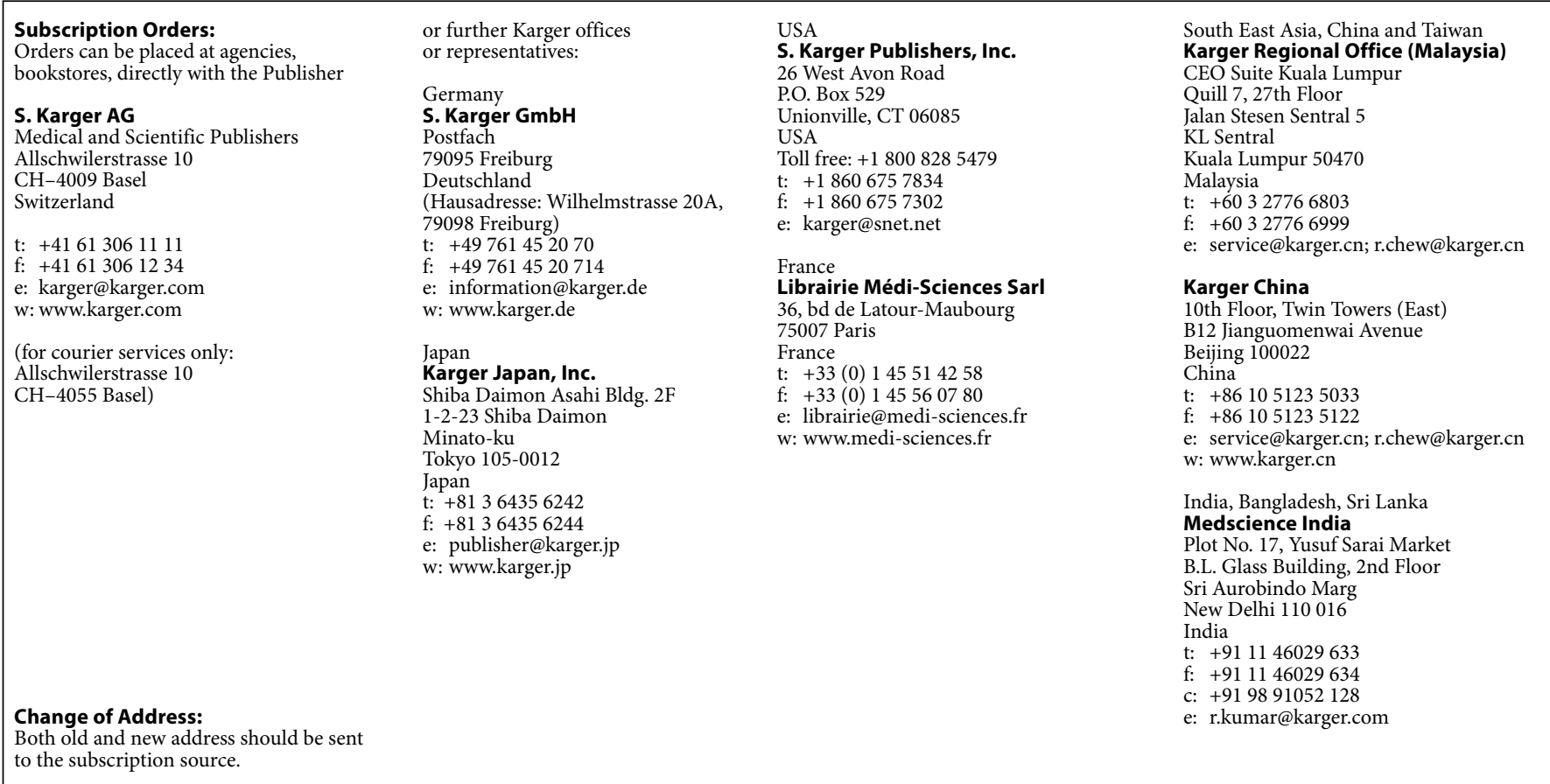

\section{KARGER}

E-Mail karger@karger.com www.karger.com

\section{(C) 2013 S. Karger AG, Basel}

The Journal Home Page is available at: www.karger.com/anm 


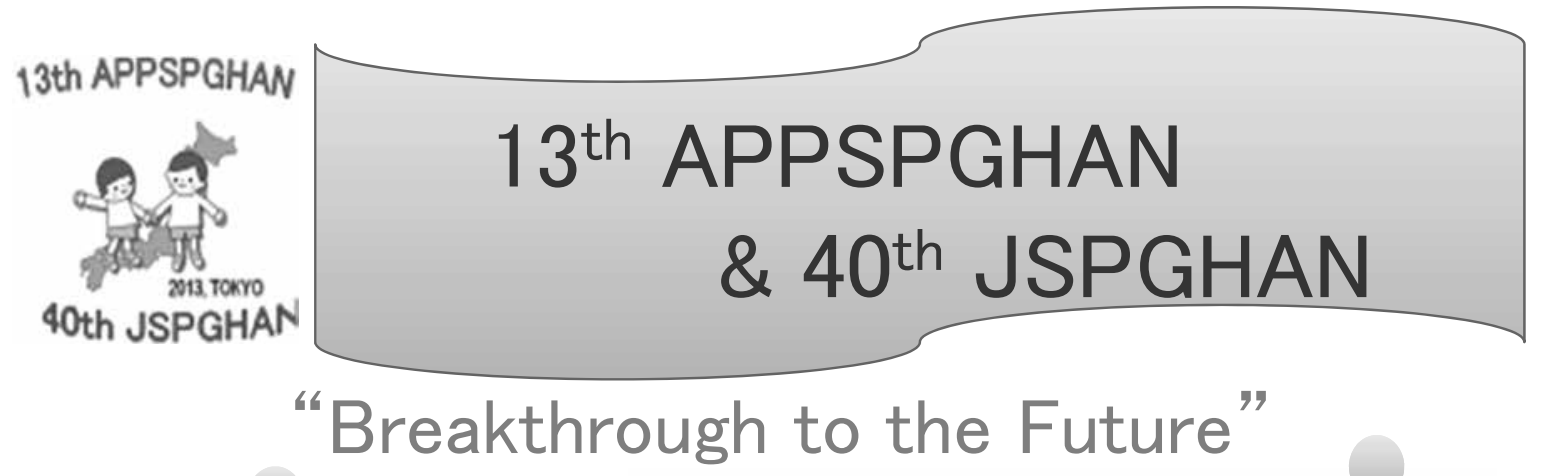

Date:

October 31 - November 3, 2013

Venue:

National Center of Sciences Building, 2-1-2 Hitotsubashi, Chiyoda-ku, Tokyo, Japan

\section{Presidents:}

Akira Matsui (President 13th APPSPGHAN) Hiroshi Tamai (President 40th JSPGHAN)

Registration Fees : * On site registration only.

Delegate 30,000 JPY

Nurse and Co-medical worker 10,000 JPY

Website: http://appghn13.umin.jp 


\section{Contents}

See the journal website for contents

KARGER $\quad$ Basel $\cdot$ Freiburg $\bullet$ Paris $\bullet$ London $\bullet$ New York $\cdot$ New Delhi $•$ Bangkok $•$ Beijing $\bullet$ Tokyo $\bullet$ Kuala Lumpur $\cdot$ Singapore $\bullet$ Sydney 


\section{Nutrition \& Metabolism}

\section{Aims and Scope}

The journal focuses on human nutrition and metabolism and related areas, including experimental studies and basic science that can inform human nutrition science. We welcome manuscripts describing observational and intervention studies as well as basic science reports on the topics of foods, diets and dietary supplements, nutrigenomics and genetics related to metabolism, on energy metabolism, macro- and micronutrients including vitamins and minerals, biofunctional compounds, dietetics, obesity, clinical nutrition social sciences and health economy as related to nutrition and metabolism and nutrition policy. Laboratorybased science may include descriptions of relevant experimental models. In addition to Original Papers, the journal will publish Review Articles on topical subjects, Systematic Reviews, short Commentaries and Viewpoint articles that may address current controversies, short Meeting Reports, Letters to the Editor, and Announcements/Society News. The journal will also publish Supplements with proceedings from internationally relevant conferences on nutrition and metabolism.

\section{Submission}

Manuscripts written in English are considered and should be submitted online at

\section{www.karger.com/anm}

Authors may suggest up to four Referees who have expert knowledge on the subject. Suggested Referees should not be from the same institution, not have published with the authors during the last 5 years, and should not be prejudiced.

Should you experience problems with your submission, please contact
Prof. Dr. B. Koletzko
Div. Metabolic and Nutritional Medicine
Dr. von Hauner Children's Hospital
Ludwig-Maximilians-University of Munich
Lindwurmstrasse 4
D-80337 Munich (Germany)
Tel. + +498951602826
E-Mail ANM@med.uni-muenchen.de

\section{Conditions}

All manuscripts are subject to editorial review. Manuscripts are received with the explicit understanding that they are not under simultaneous consideration by any other publication. Submission of an article for publication implies transfer of the copyright from the author to the publisher upon acceptance. Accepted papers become the permanent property of Annals of Nutrition and Metabolism and may not be reproduced by any means, in whole or in part, without the written consent of the publisher. It is the author's responsibility to obtain permission to reproduce illustrations, tables, etc. from other publications.

\section{Types of Articles}

The journal consists of the following sections:

Original Papers are full-length research papers which will be considered for the journal. Articles cover topics relevant to clinical studies. Basic and experimenta work appear only if directly related to clinical issues (max. 2,500 words)

Review Articles/Systematic Reviews in which a specific field is reviewed through an exhaustive literature survey. An Abstract is required and should be divided into
Background, Summary and Key Messages. Review Articles should consist of a maximum of 4,000 words.

Commentaries and Viewpoint of an editorial nature may be submitted to the journal. In these communications, usual manuscript subdivisions do not apply, and a summary statement is not needed; however, a very brief reference list may be included (max. 500 words).

Meeting Reports are brief summaries of scientific meetings in the field of nutrition and metabolism. Authors should write a letter to the Editors inquiring about potential interest before submitting the paper $(\max .1,500$ words).

Letters to the Editor are encouraged if they directly concern articles previously published in this journal or clinical subjects related to the matters discussed. The editor reserves the right to submit copies of such letters to the authors of the articles concerned prior to publication in order to permit them to respond in the same issue of the journal (max. 500 words).

Editorials are usually invited by the Editor (max. 1,000 words). Please send suggestions to the Editor.

Authors are referred to the uniform requirements for manuscripts submitted to biomedical journals (http://www.icmje.org/ethical_lauthor.html) for further guidance.

\section{Conflicts of Interest}

Authors are required to disclose any sponsorship or funding arrangements relating to their research and al authors should disclose any possible conflicts of interest. Conflict of interest statements will be published at the end of the article.

\section{Ethics}

Published research must comply with the guidelines for human studies and animal welfare regulations. Authors should state that subjects have given their informed consent and that the study protocol has been approved by the institute's committee on human research. Further, they should also state that animal experiments conform to institutional standards.

\section{Plagiarism Policy}

Plagiarism is misrepresenting somebody else's published intellectual work-product as your own (Note, this definition excludes 'self-plagiarism'). In short, it is a misuse of source material. Whether intentional or unintentional, plagiarism is a serious violation of the Annals of Nutrition and Metabolism policy. Periodically, manuscripts are screened for plagiarism and if your manuscript is found to be consistent with what the Editors define $e^{*}$ as plagiarism prior to review of the manuscript then:

- it will be rejected without review and the author(s) notified as such with a chance for rebuttal.

If a manuscript is found to contain evidence of plagiarism after acceptance and/or publication then:

- the author(s) will be notified, as in the previous situation, and offered a chance for rebuttal.

If the rebuttal arguments are not found to be satisfactory, as judged by the Editors, the manuscript will be rejected and the author sanctioned from publishing additional papers in the Journal for a period to be determined by the Editorial Board. The period of sanction imposed is dependent on the magnitude of plagiarism with a minimum sanction of one year.
If a manuscript already published in the Journal is found to exhibit evidence of plagiarism as defined by the Editors ${ }^{*}$, then we will request a retraction.

${ }^{\star}$ Definition of plagiarism - a $25 \%$ similarity in the Results or Discussion that exactly reproduces another paper.

\section{Arrangement}

Title page: The first page of each paper should indicate the title, the authors' names, the institute where the work was conducted, and a short title for use as running head.

Full address: The exact postal address of the corresponding author complete with postal code must be given at the bottom of the title page. Please also sup ply phone and fax numbers, as well as e-mail address.

Key words: For indexing purposes, a list of 3-10 key words in English is essential.

Abstracts of Reviews: Should be divided into the following subsections: Background, Summary and Key Messages. The Background should provide a brief clinical context for the review and is followed by the Summary, which should include a concise description of the main topics covered in the text. The Key Messages encapsulate the main conclusions of the review.

Abstract: Each paper needs an abstract of up to 200 words. It should be structured as follows:

Background/Aims: What is the major problem that prompted the study?

Methods: $\quad$ How was the study performed?

Results: Most important findings?

Conclusion: Most important conclusion?

Footnotes: Avoid footnotes.

Tables and illustrations: Tables are part of the text. Place them at the end of the text file. Illustration data must be stored as separate files. Do not integrate figures into the text. Electronically submitted $\mathrm{b} / \mathrm{w}$ half-tone and color illustrations must have a final resolution of $300 \mathrm{dpi}$ after scaling, line drawings one of $800-1,200 \mathrm{dpi}$.

\section{Color illustrations}

Online edition: Color illustrations are reproduced free of charge. In the print version, the illustrations are reproduced in black and white. Please avoid referring to the colors in the text and figure legends.

Print edition: Up to 6 color illustrations per page can be integrated within the text at CHF 800.- per page.

References: In the text, identify references by Arabic numerals [in square brackets]. Material submitted for publication but not yet accepted should be noted as [unpublished data] and not be included in the reference list. The list of references should include only those publications which are cited in the text. Do not alphabetize; number references in the order in which they are first mentioned in the text. The surnames of the authors followed by initials should be given. There should be no punctuation other than a comma to separate the authors. Preferably, please cite all authors. Abbreviate journal names according to the Index Medicus system. Also see International Committee of Medical Journal Editors: Uniform requirements for manuscripts submitted to biomedical journals (www.icmje.org).

Examples

(a) Papers published in periodicals: Chatel J-M, Bernard $\mathrm{H}$, Orson FM: Isolation and characterization of two complete Ara h 2 isoforms cDNA. Int Arch Allergy Immunol 2003;131:14-18.

\section{KARGER}

E-Mail karger@karger.com www.karger.com
(C) 2013 S. Karger AG, Basel 


\section{Nutrition\& Metabolism}

(b) Papers published only with DOI numbers:

Theoharides TC, Boucher W, Spear K: Serum interleukin-6 reflects disease severity and osteoporosis in mastocytosis patients. Int Arch Allergy Immunol DOI: $10.1159 / 000063858$

(c) Monographs: Matthews DE, Farewell VT: Using and Understanding Medical Statistics, ed 3, revised. Basel, Karger, 1996.

(d) Edited books: DuBois RN: Cyclooxygenase-2 and colorectal cancer; in Dannenberg AJ, Dubois RN (eds): COX-2. Prog Exp Tum Res. Basel, Karger, 2003, vol 37, pp 124-137.

Reference Management Software: Use of EndNote is recommended for easy management and formatting of citations and reference lists.

Digital Object Identifier (DOI)

S. Karger Publishers supports DOIs as unique identifiers for articles. A DOI number will be printed on the title page of each article. DOIs can be useful in the future for identifying and citing articles published online without volume or issue information. More information can be found at www.doi.org.

\section{Supplementary Material}

Supplementary material is restricted to additional data that are not necessary for the scientific integrity and conclusions of the paper. Please note that all supplementary files will undergo editorial review and should be submitted together with the original manuscript The Editors reserve the right to limit the scope and length of the supplementary material. Supplementary material must meet production quality standards for
Web publication without the need for any modification or editing. In general, supplementary files should not exceed $10 \mathrm{Mb}$ in size. All figures and tables should have titles and legends and all files should be supplied separately and named clearly. Acceptable files and formats are: Word or PDF files, Excel spreadsheets (only if the data cannot be converted properly to a PDF file), and video files (.mov, .avi, .mpeg)

\section{Author's Choice ${ }^{\mathrm{TM}}$}

Karger's Author's Choice ${ }^{\mathrm{TM}}$ service broadens the reach of your article and gives all users worldwide free and full access for reading, downloading and printing at www.karger.com. The option is available for a onetime fee of CHF 3,000.-, which is a permissible cost in grant allocation. More information can be found at www.karger.com/authors_choice.

\section{NIH-Funded Research}

The U.S. National Institutes of Health (NIH) mandates under the NIH Public Access Policy that final, peer-reviewed manuscripts appear in its digital database within 12 months of the official publication date. As a service to authors, Karger submits the final version of your article on your behalf to PubMed Central. For those selecting our premium Author's Choice ${ }^{\mathrm{TM}}$ service, we will send your article immediately upon publishing, accelerating the accessibility of your work without the usual embargo. More details on NIH's Public Access Policy is available at http://publicaccess.nih.gov/FAQ.htm\#al

\section{Self-Archiving}

Karger permits authors to archive their pre-prints (i.e. pre-refereeing) or post-prints (i.e. final draft post-refereeing) on their personal or institution's servers, provided the following conditions are met: Articles may not be used for commercial purposes, must be linked to the publisher's version, and must acknowledge the publisher's copyright. Authors selecting Karger's Author's Choice ${ }^{\mathrm{TM}}$ feature, however, are also permitted to archive the final, published version of their article, which includes copyediting and design improvements as well as citation links.

\section{Page Charges}

There are no page charges for papers of 3 or fewer printed pages (including tables, illustrations and references). Each additional complete or partial page is charged to the author at CHF 325.-. The allotted size of a paper is equal to approx. 10 manuscript pages (including tables, illustrations and references).

\section{Proofs}

Unless indicated otherwise, proofs are sent to the firstnamed author and should be returned with the least possible delay. Alterations made in proofs, other than the correction of printer's errors, are charged to the author.

\section{Reprints}

Order forms and a price list are sent with the proofs. Orders submitted after the issue is printed are subject to considerably higher prices.

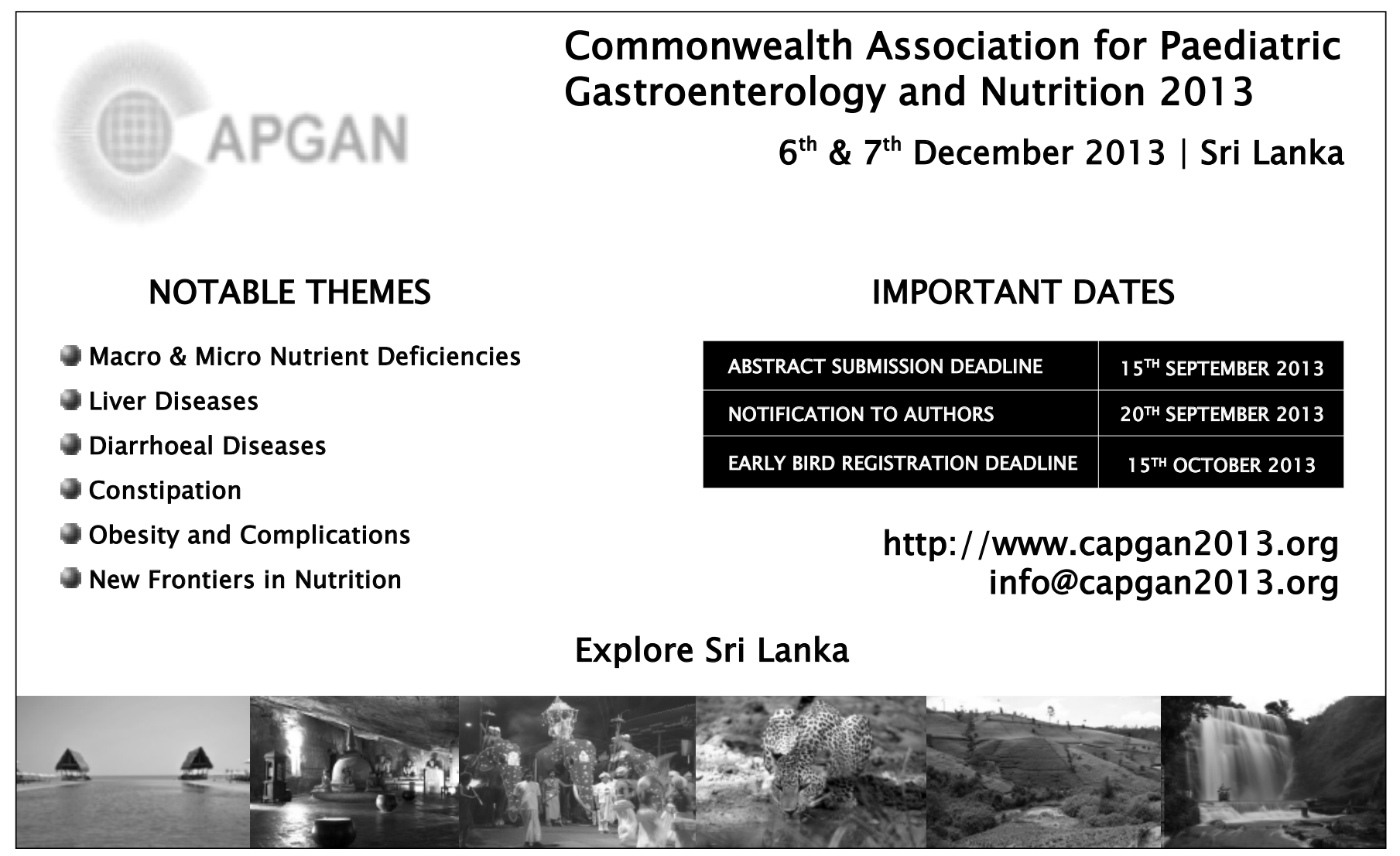




\section{ENLP Seminar 2014}

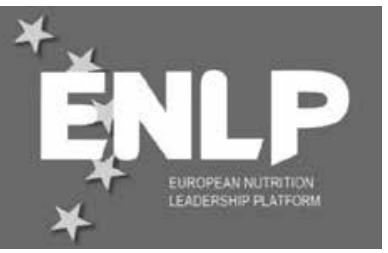

$20^{\text {th }}$ Seminar of the European Nutrition Leadership Platform, Luxembourg

Luxembourg, 9 - 17 April 2014

Course directors: Professor Renger Witkamp, PhD and Karin van het Hof, PhD

The aim of the SEMINAR of the European Nutrition Leadership Platform (ENLP) is to assist in the development of future leaders in the field of human nutrition in Europe.

Emphasis is given to

- understanding the qualities and skills of leaders,

- team building,

- communication of nutrition information in a broader context,

- and to understanding the role of nutrition science in society.

The participants of the 2003 seminar aptly expressed the vision of the seminars as follows: 'To provide a European platform where young nutritionists meet in harmony, realise their potential and leave as leaders'. Seminars have been held annually since 1994, except in 1999.

These seminars are not focused on science, but on other skills and behavioural competencies, which future leaders need to have. Therefore, professional trainers in team building, communication and leadership are invited to lecture and discuss individual skills and competencies. The seminar is organised by a group of leading European nutritionists in close collaboration with academics from a consortium of European universities and research institutes (ENABLE) and funded by the European food industry.

The seminar's programme is designed for ambitious final year PhD students and postdoctoral fellows or early-stage researchers in human nutrition science in Europe. Nutrition professionals with an MSc or PhD degree in nutrition or related sciences, who have several years of professional experience in the area of food/nutrition and health, are also invited to apply. Applications are welcome especially from countries which have been under-represented until now, e.g. the new EU member states in Eastern and Central Europe and to a lesser extent the southern European countries. Non-European candidates may be selected if they intend to build up a career in Europe.

Preference will be given to candidates under the age of 35 years. Thirty candidates will be selected by an independent international selection committee to attend the seminar.

Participation fee is Euro 1500, including full board and lodging at the seminar's venue in Luxembourg. It is possible to apply for financial support towards the fee and/or travel expenses.

Deadline for applications: 15 November 2013.

More information and the application form can be found on the website: www.enlp.eu.com. Or contact the secretariat:

: Mrs L.A. Duym, Division of Human Nutrition, Wageningen University, P.O. Box 8129, 6700 EV Wageningen, The Netherlands, tel. +31 317 483054, fax +31 317 483342, email: lous.duym@wur.nl
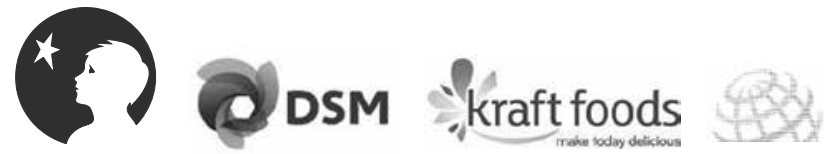


\section{ENLP Advanced Seminar 2014}

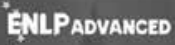

.

3rd Seminar of the European Nutrition Leadership Platform Advanced Seminar 2014 Luxembourg, 9 - 17 April 2014

Course Director: Claire MacEvilly MSc, ENLP Graduate 2003

The aim of the ADVANCED SEMINAR of the European Nutrition Leadership Platform (ENLP) is to assist in the development of leaders in the field of human nutrition in Europe. The ENLP vision is: "To develop, inspire and connect leaders within Europe to advance nutrition and health"

ENLP encompasses two seminars: ENLP Seminar and ENLP ADVANCED SEMINAR. Both provide training on the qualities and skills of leaders, team building, communication of nutrition information in a broader context, and understanding the role of nutrition science in society. The seminars are not focused on nutrition science, but on other skills and behavioural competencies, which leaders need to have. The courses are given by professionals trainers in team building, communication and leadership.

The ENLP Seminar, targeted at ambitious nutrition scientists generally at the start of their career has been held since 1994. With 30 participants attending each year an active network of over 500 graduates from the programme was created.

ENLP ADVANCED is a highly practical Leadership Skills Programme specially designed for senior managers in the nutrition, food and health sectors who would like to further their career by developing or refreshing their management and leadership skills. It has been designed for us by Greenbank, a leading international leadership consultancy and is run just once a year, in Luxembourg. Participants receive a high degree of 1-1 coaching and development.

ENLP ADVANCED is restricted to a maximum of 12 people, who will be selected by an independent international selection committee on the basis of their application. The costs of the ENLP ADVANCED are $€ 1500$ for participants from Research and Non for Profits Organisations and €3000 for participants from Industry. This includes three full days of advanced leadership training and full board and lodging from the evening of 9 April to the morning of 13 April 2014 at the Advanced Seminar hotel. Travel, insurance and personal costs such as drinks and phone calls are not included. It is possible to apply for financial support towards the fee and/or travel expenses.

The ENLP is organised by a group of leading European nutritionists in close collaboration with academics from a consortium of European universities and research institutes (ENABLE) and funded by the European food industry.

Applications should be received at the ENLP secretariat at the latest on 15 November 2013. Candidates will be informed of the decision of the selection committee by mid January 2014.

The application form is also available on the internet at: www.enlp.eu.com or you may contact: Lous.Duym@wur.nl

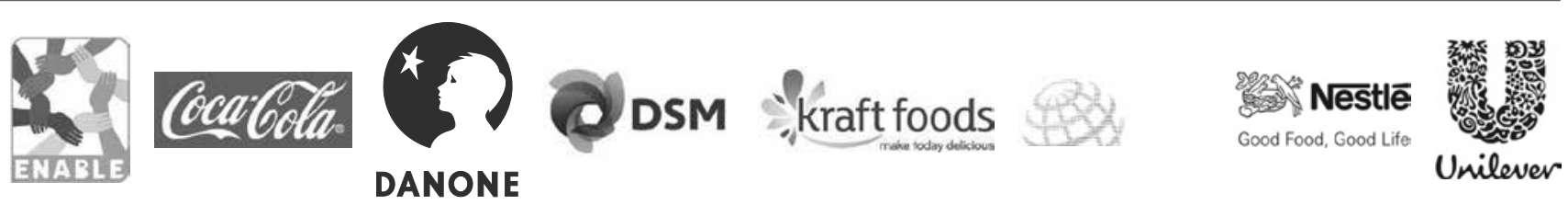




\section{An interdisciplinary journal on human and clinical nutrition}

\section{Annals of \\ Nutrition\& Metabolism}

Editor

B. Koletzko, Munich

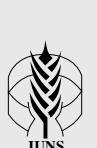

An Official Journal of the

International Union of Nutritional Sciences (IUNS) (FENS)

fens
Federation of European Nutrition Societies

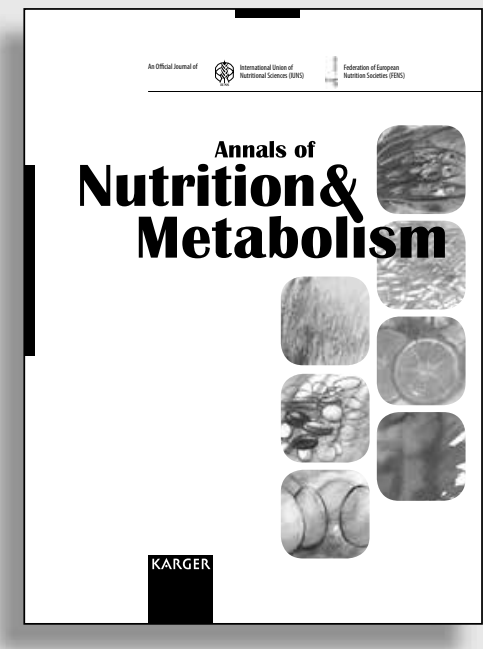

European Nutraceutical Association (ENA)

Deutsche Gesellschaft für Ernährung (DGE)
More information at

\section{www.karger.com/anm}

- Pay-per-View and Subscriber Access to Full Text

- Full Table of Contents

- Full Editorial Board

- Free Abstracts and Selected Articles

- Online Sample Issue

- Submission/Guidelines for Authors

- Subscription Details

- Free Alert Service

- Online Library Recommendation

nnals of Nutrition and Metabolism 2014: Volumes 64, 65

4 issues per volume

Language: English

ISSN 0250-6807 (print)

ISSN 1421-9697 (online)

Listed in bibliographic services, including Current Contents ${ }^{\oplus}$, MEDLINE, Biological Abstracts, EMBASE/ExcerptaMedica

\section{Selected contributions}

- Gender Differences in the Long-Chain Polyunsaturated Fatty Acid Status: Systematic Review of 51 Publications: Lohner, S.; Fekete, K.; Marosvölgyi, T.; Decsi, T. (Pécs)

- Effect of Hypoxic-Ischemic Insults on the Composition of Fatty Acids in the Brain of Neonatal Rats: Suganuma, H.; Okumura, A. (Tokyo); Kitamura, Y. (Kanagawa); Shoji, H.; Shimizu, T. (Tokyo)

- Compositional Requirements of Follow-Up Formula for Use in Infancy: Recommendations of an International Expert Group Coordinated by the Early Nutrition Academy: Koletzko, B. (Munich); Bhutta, Z.A. (Karachi); Cai, W. (Shanghai); Cruchet, S. (Santiago de Chile); Guindi, M.E. (Menoufiya); Fuchs, G.J. (Little Rock, Ark.); Goddard, E.A. (Cape Town); van Goudoever, J.B. (Amsterdam); Quak, S.H. (Singapore); Kulkarni, B. (Hyderabad); Makrides, M. (Adelaide, S.A.); Ribeiro, H. (Salvador); Walker, A. (Boston, Mass.)

- Similarities in Serum Acylcarnitine Patterns in Type 1 and Type 2 Diabetes Mellitus and in Metabolic Syndrome: Bene, J.; Márton, M.; Mohás, M. (Pécs); Bagosi, Z.; Bujtor, Z.; Oroszlán, T.; Gasztonyi, B. (Zalaegerszeg); Wittmann, I.; Melegh, B. (Pécs)

- Effects of Trans-Fatty Acids on Liver Lipid Metabolism in Mice Fed on Diets Showing Different Fatty Acid Composition: Saín, J.; González, M.A. (Santa Fe); Lasa, A. (Vitoria); Scalerandi, M.V.; Bernal, C.A. (Santa Fe); Portillo, M.P. (Vitoria)

- Probiotic Mechanisms of Action: Bermudez-Brito, M.; Plaza-Díaz, J.; Muñoz-Quezada, S.; Gómez-Llorente, C.; Gil, A. (Armilla)

- Determination of Creatinine in Human Urine with Flow Injection Tandem Mass Spectrometry: Niesser, M.; Koletzko, B.; Peissner, W. (Munich)

- Adherence Issues in Inherited Metabolic Disorders Treated by Low Natural

Protein Diets MacDonald, A. (Birmingham); van Rijn, M. (Groningen);

Feillet, F. (Vandoeuvre-les-Nancy); Lund, A.M. (Copenhagen); Bernstein, L. (Aurora, Colo.); Bosch, A.M. (Amsterdam); Gizewska, M. (Szczecin); van Spronsen, F.J. (Groningen)
Annals of Nutrition and Metabolism is a leading international peer-reviewed journal for sharing information on human nutrition, metabolism and related fields, covering the broad and multidisciplinary nature of science in nutrition and metabolism. The journal focuses on human nutrition and metabolism and related areas, including experimental studies and basic science that can inform human nutrition science. We welcome manuscripts describing observational and intervention studies as well as basic science reports on the topics of foods, diets and dietary supplements, nutrigenomics and genetics related to metabolism, on energy metabolism, macro- and micronutrients including vitamins and minerals, biofunctional compounds, dietetics, obesity, clinical nutrition, social sciences and health economy as related to nutrition and metabolism and nutrition policy. Laboratory-based science may include descriptions of relevant experimental models. In addition to Original $\mathrm{Pa}$ pers, the journal will publish Review Articles on topical subjects, Systematic Reviews, short Commentaries and Viewpoint articles that may address current controversies, short Meeting Reports, Letters to the Editor, and Announcements/ Society News. The journal will also publish Supplements with proceedings from internationally relevant conferences on nutrition and metabolism. 


\section{Karger Publications in Nutrition}

.

\section{World Review of Nutrition and Dietetics}

www.karger.com/wrund

Series Editor

B. Koletzko, Munich
政

Vol. 10

Nutrition in

Intensive Care Medicine:

Beyond Physiology

E. Sitor

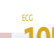

105

$144 / 63$

99

- 31 1.
Nutrition and Growth

Vol. 105

Nutrition in Intensive Care Medicine: Beyond Physiology

Vol. 104

The Vitamin A Story. Lifting the Shadow of Death

Vol. 103

Manual on Vitamin A Deficiency Disorders (VADD)

\section{Annals of Nutrition and Metabolism}

www.karger.com/anm

Current IF: 2.257

Editor

B. Koletzko, Munich

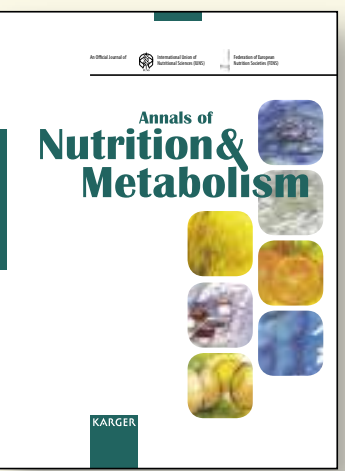

Official Journal of the

IUNS

International

Union of Nutritional

Sciences (IUNS)

Federation of European Nutrition Societies (FENS)

fens
CNA European Association (ENA)

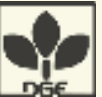

Deutsche Gesellschaft für Ernährung (DGE)

\section{Journal of Nutrigenetics and Nutrigenomics}

www.karger.com/jnn

Current IF: 1.143

Editor

J.X. Kang

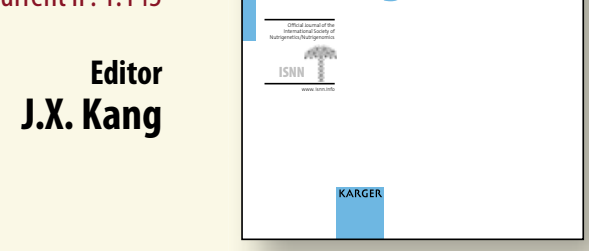

Official Journal of the

Aotom International Society of

$\| S$ IN/N N Nutrigenetics/

Nutrigenomics (ISNN)

\section{Nestlé Nutrition Institute Workshop Series}

www.karger.com/nniws

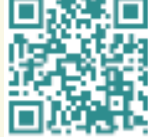

www.karger.com/nutrition

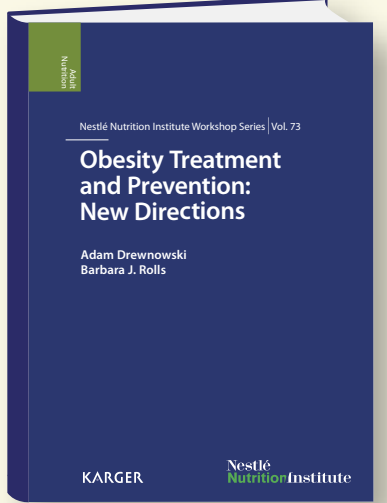

Vol. 73

Obesity Treatment and Prevention: New Directions

Vol. 72

Stepping Stones to Living Well with Dysphagia

Vol.71

Recent Advances in Growth Research:

Nutritional, Molecular and Endocrine Perspectives

Vol. 70

Meeting Micronutrient Requirements for

Health and Development

KARGER 